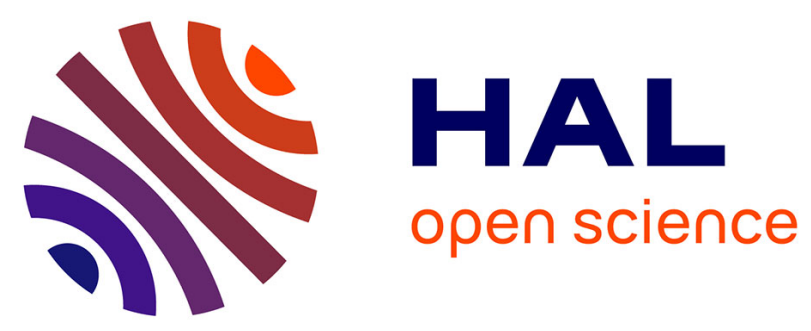

\title{
Development of a realistic phantom of a mouse's head : application to photoacoustic temperature monitoring during photothermal therapy
}

Antoine Capart, Khaled Metwally, Chiara Bastiancich, Anabela da Silva

\section{To cite this version:}

Antoine Capart, Khaled Metwally, Chiara Bastiancich, Anabela da Silva. Development of a realistic phantom of a mouse's head: application to photoacoustic temperature monitoring during photothermal therapy. European Conferences on Biomedical Optics OSA/SPIE (ECBO 2021), Jun 2021, Munich, Germany. hal-03313518

\author{
HAL Id: hal-03313518 \\ https://hal.science/hal-03313518
}

Submitted on 4 Aug 2021

HAL is a multi-disciplinary open access archive for the deposit and dissemination of scientific research documents, whether they are published or not. The documents may come from teaching and research institutions in France or abroad, or from public or private research centers.
L'archive ouverte pluridisciplinaire $\mathbf{H A L}$, est destinée au dépôt et à la diffusion de documents scientifiques de niveau recherche, publiés ou non, émanant des établissements d'enseignement et de recherche français ou étrangers, des laboratoires publics ou privés. 


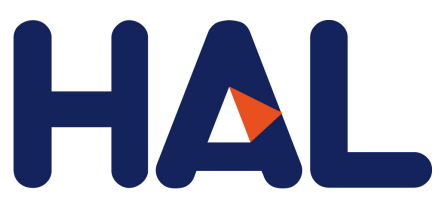

archives-ouvertes

\section{Development of a realistic phantom of a mouse's head : application to photoacoustic temperature monitoring during photothermal therapy}

Antoine Capart, Khaled Metwally, Chiara Bastiancich, Anabela da Silva

\section{To cite this version:}

Antoine Capart, Khaled Metwally, Chiara Bastiancich, Anabela da Silva. Development of a realistic phantom of a mouse's head: application to photoacoustic temperature monitoring during photothermal therapy. European Conferences on Biomedical Optics OSA/SPIE (ECBO 2021), Jun 2021, Munich, Germany. hal-03313518

\section{HAL Id: hal-03313518 \\ https://hal.archives-ouvertes.fr/hal-03313518}

Submitted on 4 Aug 2021

HAL is a multi-disciplinary open access archive for the deposit and dissemination of scientific research documents, whether they are published or not. The documents may come from teaching and research institutions in France or abroad, or from public or private research centers.
L'archive ouverte pluridisciplinaire HAL, est destinée au dépôt et à la diffusion de documents scientifiques de niveau recherche, publiés ou non, émanant des établissements d'enseignement et de recherche français ou étrangers, des laboratoires publics ou privés. 


\title{
Development of a realistic phantom of a mouse's head : application to photoacoustic temperature monitoring during photothermal therapy
}

\author{
Antoine Capart ${ }^{1, *}$, Khaled Metwally ${ }^{1,2}$, Chiara Bastiancich ${ }^{3}$ and Anabela Da Silva ${ }^{1}$ \\ ${ }^{1}$ Aix Marseille Univ, CNRS, Centrale Marseille, Institut Fresnel, Marseille, France \\ ${ }^{2}$ Aix Marseille Univ, CNRS, Centrale Marseille, LMA, Marseille, France \\ ${ }^{3}$ Aix Marseille Univ, CNRS, UMR 7051 Institut Neurophysiopathologie, Marseille, France \\ *antoine.capart@fresnel.fr
}

\begin{abstract}
We developed a numerical phantom of a mouse's head where we performed photothermal therapy on a tumor. Nanoparticles are numerically added and their effects are studied. The medium's temperature was monitored using the photoacoustic technique. (C) 2021 The Author(s)
\end{abstract}

PhotoThermal Therapy (PTT) refers to the use of optical radiation, usually near infrared light, in order to treat diverse medical conditions, most commonly, cancer. Light received by the tissues is absorbed and converted into heat leading to rises in temperatures, which in turn lead to the death of the cells and their thermal ablation. In PTT, optical absorbers are commonly used in order to increase the efficiency of the treatment and target specific area. Usually, metallic nanoparticles (NPs) are used as they show strong tunable absorption.

In the recent years, PTT gained an important popularity due to its localized and non invasive treatment advantage. With its constant improvement, new efficient numerical tools are developed for the simulation of the therapy in order to confront simulated to experimental results. Following these approaches and with the aim of enlightening experimental results, we developed a numerical phantom of a mouse's head where PTT was performed. The phantom was built using atlas obtained with different imaging methods and available online [1-4] to numerically recreate the more precisely possible the morphology of the mouse's head. Moreover, a particular attention has been paid to the physical parameters needed for the numerical simulations : a thorough literature review was performed to design this highly realistic phantom. The case of a tumorous brain was considered and compared to the reference case of a healthy brain. The phantom is presented in Fig. 1, and the position of the tumor is indicated. Additionally, NPs were added numerically in the brain : their effect was simulated by a local increase of the ab-


Fig. 1. Phantom of a mouse's head : 2D sagittal and cortical view of the phantom. Tumor's contour is indicated by the dashed purple line.

sorption properties. Different cases were considered in the form of different local increases. The results obtained were compared to understand the effect of the tumor and the NPs on the therapy.

During the therapy, a real-time temperature monitoring method is needed in order to control the thermal damages caused to the tumor and its surroundings. For such purpose, the PhotoAcoustic (PA) technique has been 
shown to be a good candidate, as it allows for in depth, non invasive real-time temperature monitoring. [5-7]. As temperature change in the phantom, the PA signal undergoes variations in amplitude. This dependency was implemented in the phantom. It is therefore possible to link these variations in amplitude to the increase of temperature.

To numerically simulate the therapy, the heat generated by the light source has been calculated using the Monte Carlo method. Heat diffusion simulations were then performed on the phantom by solving Penne's bioheat equation [8]. Finally, PA simulations were conducted during the PTT, and variations in the signals received were studied and linked to temperature in the phantom.

With our numerical study, we manage to :

- Model the temperature evolution in the phantom and the tumor.

- Quantify the thermal damages caused to the tumor and the surrounding healthy tissues.

- Investigate the feasibility of accurate temperature monitoring through the use of the PA technique.

\section{References}

1. Y. Ma, P. R. Hof, S. C. Grant, S. J. Blackband, R. Bennett, L. Slatest, M. D. McGuigan, and H. Benveniste. A three-dimensional digital atlas database of the adult C57BL/6J mouse brain by magnetic resonance microscopy. Neuroscience, 135(4):1203-1215, January 2005.

2. E. Chan, N. Kovacevíc, S. K. Y. Ho, R. M. Henkelman, and J. T. Henderson. Development of a high resolution threedimensional surgical atlas of the murine head for strains 129S1/SvImJ and C57B1/6J using magnetic resonance imaging and micro-computed tomography. Neuroscience, 144(2):604-615, January 2007.

3. A. Dorr, J.G. Sled, and N. Kabani. Three-dimensional cerebral vasculature of the CBA mouse brain: A magnetic resonance imaging and micro computed tomography study. NeuroImage, 35(4):1409-1423, May 2007.

4. Yuming Liu, Steven L. Jacques, Mehdi Azimipour, Jeremy D. Rogers, Ramin Pashaie, and Kevin W. Eliceiri. OptogenSIM: a 3D Monte Carlo simulation platform for light delivery design in optogenetics. Biomed Opt Express, 6(12):4859-4870, November 2015.

5. Jignesh Shah, Suhyun Park, Salavat Aglyamov, Timothy Larson, Li Ma, Konstantin Sokolov, Keith Johnston, Thomas Milner, and Stanislav Y. Emelianov. Photoacoustic imaging and temperature measurement for photothermal cancer therapy. Journal of Biomedical Optics, 13(3):034024, 2008.

6. Irina V Larina, Kirill V Larin, and Rinat O Esenaliev. Real-time optoacoustic monitoring of temperature in tissues. Journal of Physics D: Applied Physics, 38(15):2633-2639, August 2005.

7. Shiou-Han Wang, Chen-Wei Wei, Shiou-Hwa Jee, and Pai-Chi Li. Photoacoustic temperature measurements for monitoring of thermal therapy. page 71771S, San Jose, CA, February 2009.

8. Harry H. Pennes. Analysis of Tissue and Arterial Blood Temperatures in the Resting Human Forearm. Journal of Applied Physiology, 1(2):93-122, August 1948. 